\title{
Salt, sediments and weathering environments in Bunger Hills
}

\author{
DAMIAN B. GORE (1) 1 and MICHELLE R. LEISHMAN ${ }^{2}$ 2 \\ ${ }^{1}$ Department of Earth and Environmental Sciences, Macquarie University, NSW 2109, Australia \\ ${ }^{2}$ Department of Biological Sciences, Macquarie University, NSW 2109, Australia \\ damian.gore@mq.edu.au
}

\begin{abstract}
Terrestrial environments at Bunger Hills, East Antarctica, vary from vegetation-rich, littleweathered rock surfaces retaining glacial polish and striations near the glacier and ice-sheet margins to salty, vegetation-poor, extensively weathered regions near to and downwind of marine bays and inlets. Weathering forms include tafoni and orientated pits, which record former wind directions. Although salts are found all over Bunger Hills, the strongly weathered area is coincident with the distribution of halite $(\mathrm{NaCl})$ and thenardite $\left(\mathrm{Na}_{2} \mathrm{SO}_{4}\right)$, both of which are derived from seawater and marine salt spray. Salts elsewhere in Bunger Hills are either subglacial calcium carbonates or rock weathering products including gypsum $\left(\mathrm{CaSO}_{4} \cdot 2 \mathrm{H}_{2} \mathrm{O}\right)$ and a range of rarer minerals. These other salt minerals do not weather rocks and sediment. The distribution of halite and thenardite acts as a major control on the geomorphology, sediment geochemistry and biogeography of Bunger Hills.
\end{abstract}

Received 14 October 2019, accepted 7 January 2020

Key words: biogeography, geochemistry, Holocene, landscape evolution, mineralogy

\section{Introduction}

The East Antarctic deglaciated oases, including Windmill Islands, Bunger Hills, Vestfold Hills and Larsemann Hills, are areas where seals, penguins and flighted birds can gather for their summer moulting, pupping and nesting. After the short summer, when these animals leave, other less mobile life, such as invertebrates, remain in the lakes, inlets and moss beds. For these transient summer visitors and more permanent animals and plants, the oases are vital places for their survival in the present day and as source areas for re-dispersion of species across Antarctica following the peaks of glacial cycles (e.g. Cromer et al. 2006, De Smet \& Gibson 2007, Pugh \& Convey 2008). Environmental conditions in these Antarctic oases such as Bunger Hills are significant, as they form a physical and chemical template upon which Antarctic biodiversity has developed and will continue to persist and evolve into the future.

Southern Bunger Hills is similar to the central (Broad) and southern (Mule) peninsulas of Vestfold Hills, some $1000 \mathrm{~km}$ to the west, in many respects. Both consist of high-grade gneiss (Tucker et al. 2020) that has been regionally planated by repeated glaciations throughout the Pleistocene, and both are low altitude, with concordant summits that are $<200 \mathrm{~m}$ above sea level. The two regions have extensive lakes and marine inlets that penetrate almost the entire width of their areas, and emergent mid-Holocene shorelines (Colhoun \& Adamson 1992, Zwartz et al. 1998) that testify to similar regional histories of glaciation and deglaciation. The area of both is similar, with southern Bunger Hills at $300 \mathrm{~km}^{2}$ compared with Vestfold Hills at $400 \mathrm{~km}^{2}$ (these values are approximate, depending on whether or not lakes and marine inlets are included and where the ice margin is plotted). Both have almost unidirectional strong winds, which have persisted for extended durations back into the Holocene and created orientated tafoni (weathering pits) in the bedrock in places (Pickard 1982, Gore \& Leishman 2020). Given these similarities in geology, geomorphology and Quaternary history, it is probable that their terrestrial environments are also similar.

At Vestfold Hills, salt has been shown to be an agent of geomorphic and sedimentary (Blandford 1975, Adamson \& Pickard 1986), geochemical (Gore et al. 1996) and biological (Pickard 1986) differentiation in the landscape. Given the other similarities of Bunger Hills with Vestfold Hills, it is reasonable to hypothesize that salt is also important for the landscape and sediments at Bunger Hills and that salt identities and their effects should be discernible.

The effects of salt on the terrestrial environment are integrated with spatial and temporal patterns of rock weathering, sediment development and biogeography. Salt crystallization and hydration pressure from various types of salts enhance granular disaggregation and the rate of rock weathering (e.g. Goudie 1986). For example, the occurrence of tafoni (weathering pits) is known to be associated with salty environments (Schnepfleitner et al. 2016), and so the distribution of these and similar weathering features might inform on interactions between salts and landscape development. The contribution of this physically weathered material over time, and through multiple glacial cycles, might also 

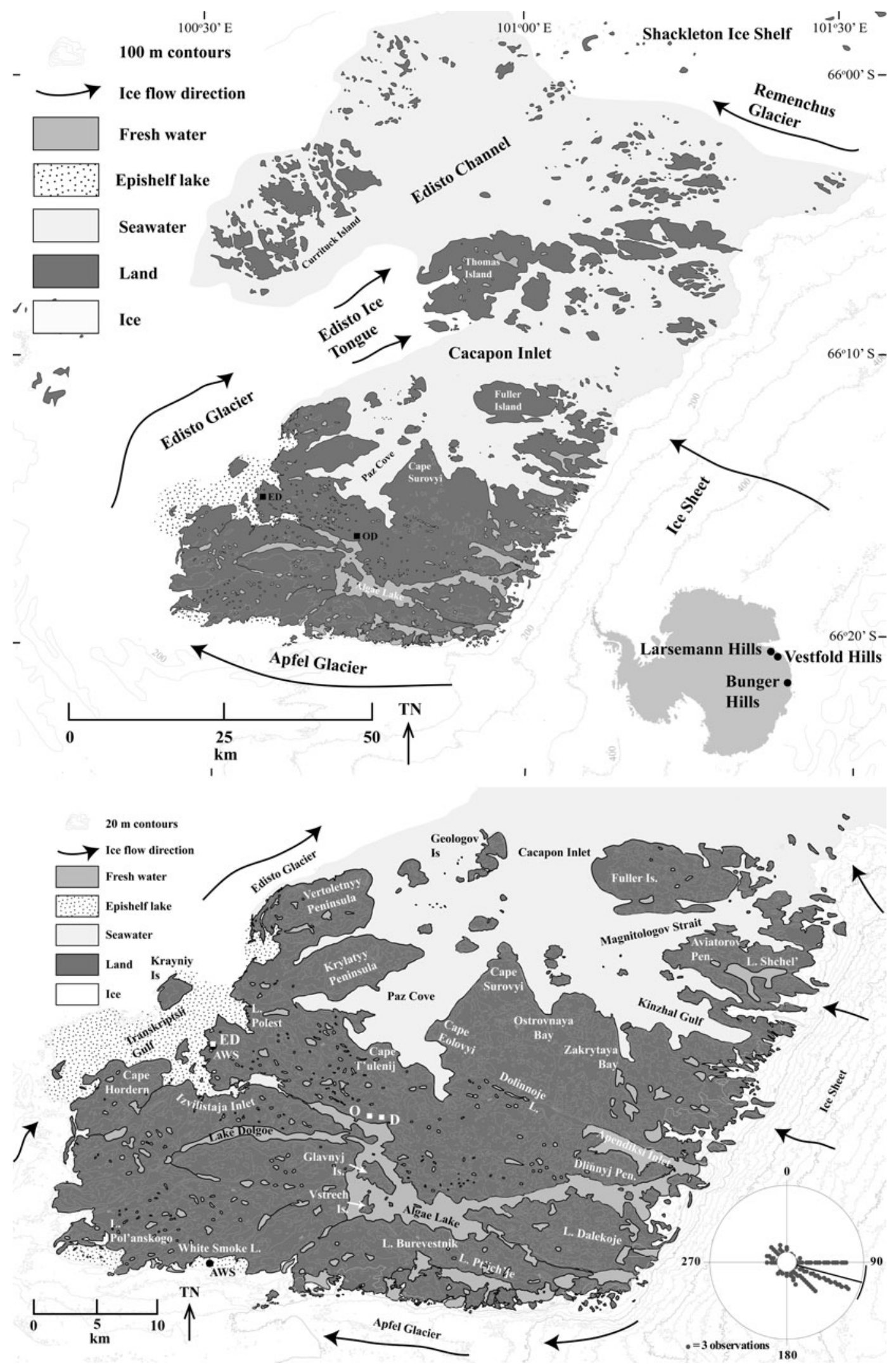

Fig. 1. Locations of Bunger Hills and sites mentioned in the text. The inset in the lower right shows the wind rose of 3-hourly wind azimuth measurements recorded at Edgeworth David Base in January-March 1986. D = Dobrowolski Station, ED = Edgeworth David Base, $\mathrm{O}=$ Oasis-2 Station. 
Table I. Field observations of erosion, deposition and periglacial features. Glacial polish and frost cracks are more common in unweathered areas, and tafoni, orientated wind pits and accumulations of sand are indicative of weathered areas. Summing the values resulted in an index that ranged from a theoretical minimum of 0.5 (the least amount of weathering) to a maximum of 5.0 (the greatest amount of weathering).

\begin{tabular}{|c|c|c|c|}
\hline Feature & Absent (score) & Present (score) & Abundant (score) \\
\hline $\begin{array}{l}\text { Erosion } \\
\text { Loss of glacial polish }\end{array}$ & $\begin{array}{l}\text { Polish is rare to absent, having } \\
\text { been removed in most places } \\
\text { by weathering. Score: } 1.0\end{array}$ & $\begin{array}{l}\text { Polish is common on the stoss sides } \\
\text { of hilltops, but in many places has been } \\
\text { removed by weathering. Score: } 0.5\end{array}$ & $\begin{array}{l}\text { Polish is abundant on stoss sides of } \\
\text { rocks and pavements. Score: } 0.1\end{array}$ \\
\hline $\begin{array}{l}\text { Erosion } \\
\text { Creation of tafoni }\end{array}$ & $\begin{array}{l}\text { Absent to rare, and the rock surface } \\
\text { appears unweathered. Score: } 0.1\end{array}$ & $\begin{array}{l}\text { Tafoni common. Most susceptible } \\
\text { lithologies have tafoni pits, while others } \\
\text { may retain glacial polish. Score: } 0.5\end{array}$ & $\begin{array}{l}\text { Tafoni abundant and well developed in } \\
\text { some clasts, with some hollowed out. } \\
\text { May form rock overhangs or caves. } \\
\text { Score: } 1.0\end{array}$ \\
\hline $\begin{array}{l}\text { Erosion } \\
\text { Creation of orientated } \\
\text { wind pits }\end{array}$ & Pits are absent to rare. Score: 0.1 & $\begin{array}{l}\text { Pits may be common on clasts or bedrock } \\
\text { in sites most exposed to wind, or in } \\
\text { finer-grained lithologies. Score: } 0.5\end{array}$ & $\begin{array}{l}\text { Pits are abundant on fine-grained } \\
\text { clasts or bedrock in windy locations. } \\
\text { Score: } 1.0\end{array}$ \\
\hline $\begin{array}{l}\text { Deposition } \\
\text { Accumulation of sand } \\
\text { from rock weathering }\end{array}$ & $\begin{array}{l}\text { Sand and fine gravel accumulations are } \\
\text { absent to rare. The original glacial } \\
\text { sediment surface is visible. Score: } 0.1\end{array}$ & $\begin{array}{l}\text { Sand and fine gravel thinly mantles the } \\
\text { underlying till or bedrock, but thick } \\
\text { accumulations are rare. Score: } 0.5\end{array}$ & $\begin{array}{l}\text { Sand and fine gravel accumulations } \\
\text { are common to abundant, thickly } \\
\text { covering bedrock or glacial sediment. } \\
\text { They may form lee-side dunes } \\
\text { downwind of cobbles or boulders, or } \\
\text { form climbing dunes on the upwind } \\
\text { side of hills or patches downwind of } \\
\text { hills. Score: } 1.0\end{array}$ \\
\hline $\begin{array}{l}\text { Freeze-thaw cycling } \\
\text { Development of frost } \\
\text { cracks in sediment }\end{array}$ & $\begin{array}{l}\text { Periglacial frost cracks are rare to absent. } \\
\text { Score: } 1.0\end{array}$ & $\begin{array}{l}\text { Frost cracks are common but not all } \\
\text { valley floor sediments exhibit frost cracks. } \\
\text { Score: } 0.5\end{array}$ & $\begin{array}{l}\text { Frost cracks are common to abundant } \\
\text { on valley floor and other flat-lying, } \\
\text { fine-grained sediments. Score: } 0.1\end{array}$ \\
\hline
\end{tabular}

change the character of the sediments, which might be reflected in their grain-size characteristics (Gore et al. 2003). Loss of glacial polish and the development of tafoni and orientated wind pits are examples of erosional processes consistent with enhanced weathering or extended time of exposure. Accumulations of salt and sand reflect the input of marine aerosols and extensive rock weathering, respectively. Frost cracks develop from freeze-thaw cycling; however, salty areas undergo fewer freeze-thaw cycles than equivalent salt-poor areas, so that a reduction in or absence of periglacial activity is consistent with abundant salt in the sediment.

At Vestfold Hills, an inverse relationship exists between the distribution of marine salts and periglacial features such as frost cracks and patterned ground (Adamson \& Pickard 1986), and similarly at Bunger Hills, these and other geomorphic features may also be related to the distribution of salt. This research explores the presence or absence of various types of salts and aims to understand their relationships with the geomorphology, sediments and terrestrial environments of Bunger Hills. Specifically, are there physical patterns of rock weathering and sediment development in Bunger Hills, and do those patterns have an association with the chemistry of solutes readily extracted from surface sediments and the mineralogy of salts on the land surface?

\section{Methods}

Bunger Hills is an ice-free area on the coast of East Antarctica (Fig. 1). It is bounded by the ice sheet to the east, Apfel Glacier to the south, Edisto Glacier to the west and Shackleton Ice Shelf to the north. Although surrounded by ice, there is a hydraulic connection with the ocean, and the marine inlets are tidal and salty. A number of epishelf lakes retain marginal hydraulic connections to the ocean under the glaciers, and they are tidal but with a thick freshwater lens. The southern part of the hills consists of $\sim 300 \mathrm{~km}^{2}$ of ice-free land, which includes hundreds of lakes and a long freshwater drainage system, Algae River (Gibson et al. 2002). The central parts of Bunger Hills were deglaciated c. $30 \mathrm{ka}$ BP (Gore et al. 2001), in contrast with the southern, eastern and western ice margins, which deglaciated during the last 10000 years during the Holocene (Berg et al. 2020). Coverage of weathered rock by ice along the ice-sheet margin (Adamson \& Colhoun 1992) and the lack of vegetation in places along the Apfel Glacier margin (https://data.aad.gov.au/eds/file/2090) indicate recent, localized ice advance and retreat, respectively.

\section{Field observations}

The Bunger Hills map was divided into a $1 \mathrm{~km}$ grid, and each grid was visited on foot at least once, and some 
grids many times, over a single summer in 1995-96. In total, $2751 \mathrm{~km}^{2}$ grids in southern Bunger Hills were visually assessed and characterized for a range of weathering indicators, including erosional, depositional and periglacial features. These indicators were: the abundance of glacial polish, tafoni and orientated wind pits on rock surfaces, accumulations of sand and frost cracks in sediment (Table I). Each of these features was recorded in the field as being absent, present or abundant and these three simple classes had a numerical value assigned (Table I). These values were summed to form an index that allowed mapping of weathering environments across the field area.

\section{Glacial debris grain size}

Samples of basal or ablation till $(n=74)$, identified in the field on the basis of fissility, consolidation and texture, were collected on a $2 \mathrm{~km}$ grid. Typically, samples were recovered from pits $0.3-1.0 \mathrm{~m}$ deep. $0.5 \mathrm{~kg}$ samples were dried at $70^{\circ} \mathrm{C}$, dispersed in sodium hexametaphosphate solution for $24 \mathrm{~h}$, then separated into two fractions by wet sieving at 2 and $0.5 \mathrm{~mm}$. The gravels $(>2 \mathrm{~mm}$ fraction) were not considered further. The coarse and very coarse sand fractions $(2.0-0.5 \mathrm{~mm})$ were assessed using a settling tube, while the remaining sand, silt and clay fractions $(0.5-0.0001 \mathrm{~mm})$ were measured using a Malvern Mastersizer 2000 optical bench with a Hydro $2000 \mathrm{G}$ accessory. A particle refractive index of 1.544 (quartz) and a water refractive index of 1.333 were used. The $\mathrm{d}_{5}$ (finest $5 \%$ of the cumulative grain-size distribution curve) was often not constrained by the methods used where particles were $<0.0001 \mathrm{~mm}$, so mean grain size, graphic standard deviation (sorting) and graphic skewness were calculated from the $d_{16}$, $\mathrm{d}_{50}$ and $\mathrm{d}_{84}$ parameters (Folk 1980) measured from a combined $<2 \mathrm{~mm}$ grain-size curve. Mean grain size $\left(=\left(\mathrm{d}_{16}+\mathrm{d}_{50}+\mathrm{d}_{84}\right) / 3\right)$ is the average of all particles in the sample, while sorting $\left.\left(=\mathrm{d}_{84}-\mathrm{d}_{16}\right) / 2\right)$ shows the similarity in size of the particles. Skewness $\left(=\left(\mathrm{d}_{16}+\mathrm{d}_{84}-2 \mathrm{~d}_{50}\right) /\left(\mathrm{d}_{84}-\mathrm{d}_{16}\right)\right)$ reveals asymmetry in the grain-size distributions. For example, positive (right) skewed distributions show that the bulk of the grain-size data are on the left, which for these sediments would mean an excess of fine-grained material. Negative (left) skewed distributions imply an excess of coarse-grained material.

\section{Surface sediment conductivity and solute elemental composition}

Scrapes of $\sim 100 \mathrm{~g}$ of the surface $2 \mathrm{~cm}$ of sediment were taken on a $1 \mathrm{~km}$ grid across the hills $(n=252)$. Surface sediments were dried at $70^{\circ} \mathrm{C}$, sieved at $2 \mathrm{~mm}$ to exclude gravels, then solutes extracted by slow rolling $10 \mathrm{~g}$ of the
$<2 \mathrm{~mm}$ fraction with $50 \mathrm{ml}$ of American Society for Testing Materials (ASTM; https://www.astm.org/ Standards/D1193.htm) Type II deionized water in glass tubes for $2.5 \mathrm{~h}$ and then centrifuging at 3000 revolutions per minute for $10 \mathrm{~min}$. Conductivity measurements were made using a Radiometer CDM 80 conductivity meter. Quadruplicate analyses of sodium $(\mathrm{Na})$, magnesium $(\mathrm{Mg})$, potassium $(\mathrm{K})$ and calcium $(\mathrm{Ca})$ were performed on a GBC Double Beam Flame Atomic Absorption Spectrophotometer Model 902, and data were averaged. Chloride $(\mathrm{Cl})$ analyses were performed in duplicate using a Radiometer ION 85 ion analyser with an $\mathrm{F} 1012 \mathrm{Cl}$ electrode and a double-bridged K701 calomel reference electrode. Measurements were converted from $\mathrm{mg} \mathrm{l}^{-1}$ to total extractable values in $\mathrm{mg} \mathrm{kg}^{-1}$. Values are untransformed, except for conductivity, which was square root transformed to help with data analysis and presentation. All data are in Tables SI-SV.

\section{Salt mineralogy}

Salts on the surface sediment were sampled where encountered $(n=122)$. In the field, white salts encountered were tasted, and many of those with similarity to table salt were not sampled in order to save field time and sampling resources and to reduce analytical burden, although as a consequence those common types of salt are underrepresented in the data. Samples were scraped or plucked from their substrates, and while care was taken to avoid incorporating the underlying rock, in many cases it could not be avoided, and rock particles even formed an integral part of some subglacial carbonates. Samples were placed in plastic Petri dishes, sealed with tape to prevent desiccation or hydration and were stored at ambient temperature until analysis. Salts were hand milled under acetone in an agate mortar and pestle to a fine powder, before mounting on silicon crystal low-background holders. Analyses were performed using a Philips PW 1404X-ray diffractometer using $\mathrm{Cu}-K_{\alpha}$ radiation from $5^{\circ}$ to $85^{\circ} 2 \theta$ in $0.05^{\circ}$ steps, and with tube power settings of $40 \mathrm{kV}$ and $40 \mathrm{~mA}$. Diffractograms were analysed using PANalytical HighScore+ software v. 2.2.1 with the 2013 International Centre for Diffraction Data Powder Diffraction File 2 inorganic mineralogical database and the FIZ Karlsruhe GmbH Inorganic Crystal Structure Database.

\section{Data analysis}

One-way analysis of variance tests (Minitab Express, version 1.5.1) were conducted between the field observations of the erosional and depositional forms, sediment conductivity and the concentration of $\mathrm{Cl}$. 

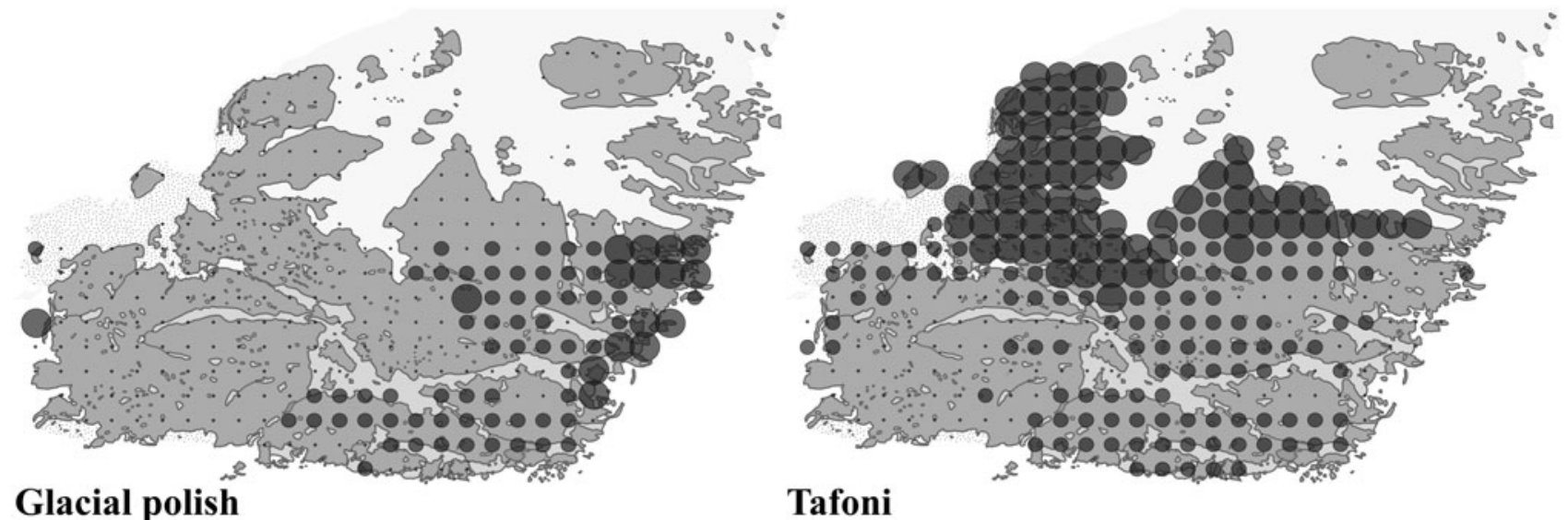

Glacial polish

Tafoni
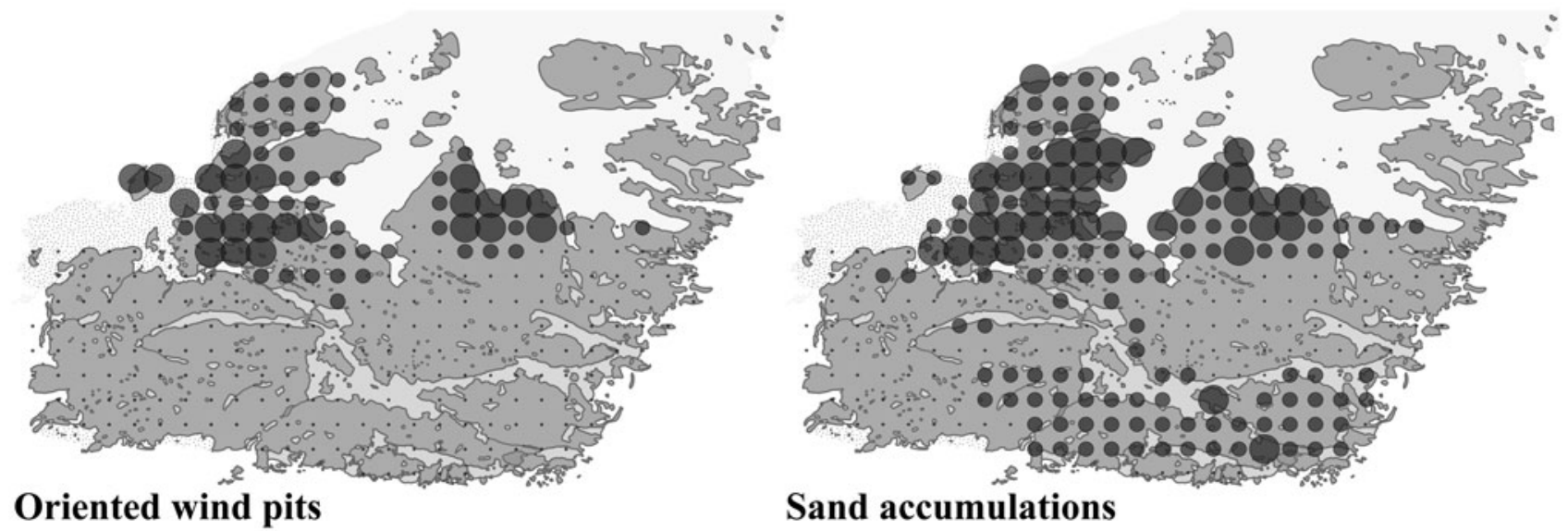

Sand accumulations
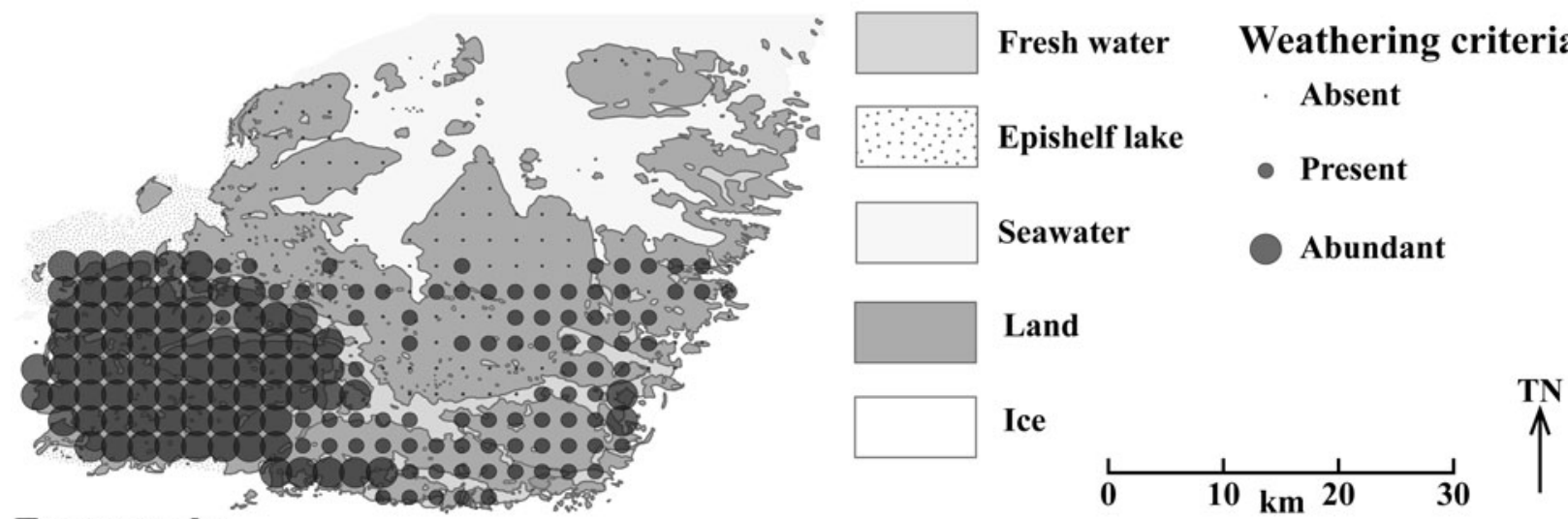

Frost cracks

Fig. 2. Distribution of erosional (glacial polish, tafoni, wind pits), depositional (sand accumulations) and periglacial (frost cracks in sediment) features in southern Bunger Hills. Features were mapped every grid kilometre as absent, present or abundant, and a numerical value was assigned and mapped.

\section{Results}

\section{Field observations}

Glacial polish on bedrock surfaces was abundant in the east of the hills adjacent to the ice sheet, with only two locations in the west close to the glacier edge having abundant polish (Figs $2 \& 3$ ). Bedrock to the east, beyond a few kilometres of the ice sheet, and areas to the south-east had only minor amounts of glacial polish. Glacial polish was rare in the centre, west, mid-west and north (Fig. 2 \& Table SI). Tafoni, orientated wind pits and sand accumulations (Figs 2 \& 3 \& Table SI) 

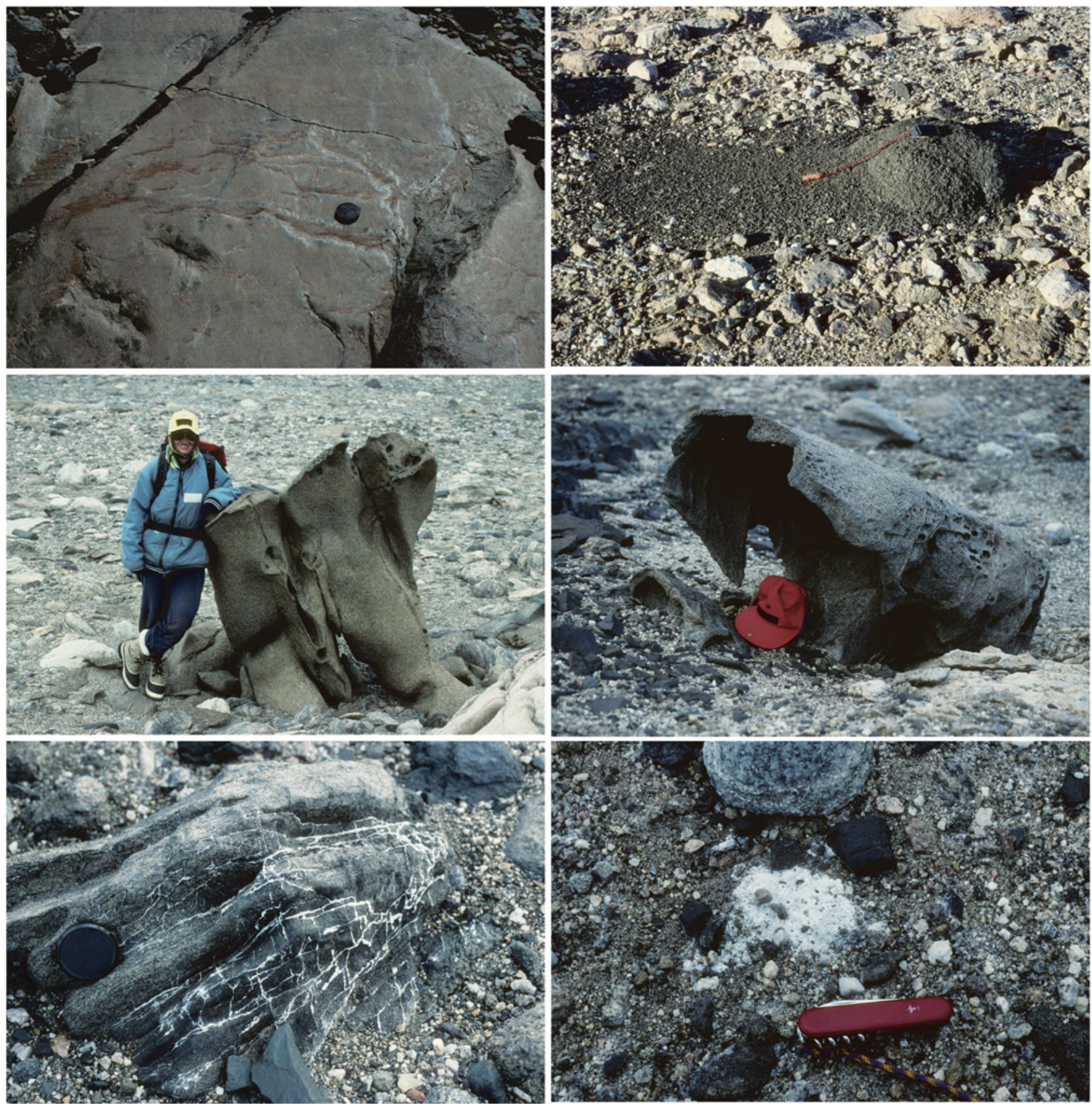

Fig. 3. Top left panel: glacial polish (lens cap is $50 \mathrm{~mm}$ diameter). Top right panel: granular disintegration of a coarse mafic clast, creating a train of sand and fine gravel spreading downwind (right to left). The compass is $80 \mathrm{~mm}$ long. Mid-left panel: granular disintegration of gneiss forming waisted boulders. Mid-right panel: cavernous weathering has hollowed out a boulder leaving the outer surface, with large amounts of sand generated by rock breakdown. Bottom left panel: halite $(\mathrm{NaCl})$ lining rock joints (lens cap is $50 \mathrm{~mm}$ diameter). Bottom right panel: halite on sediment surface (knife is $83 \mathrm{~mm}$ long).

occurred in the north of the hills, with their southern extent forming a roughly east-west line coincident with the southern ends of marine Paz Cove and Zakrytaya Bay (Fig. 1). Minor sand accumulations occurred in the south and south-east (Fig. 2). Frost cracks were only common in the south-western and southern parts of the hills; they were rarer in the south-east and east and essentially absent to the north (Fig. 2). The weathering index shows that the northern areas have the greatest scores, indicating the most weathering, while the southern and eastern areas have the lowest scores and minimal weathering (Fig. 4). 


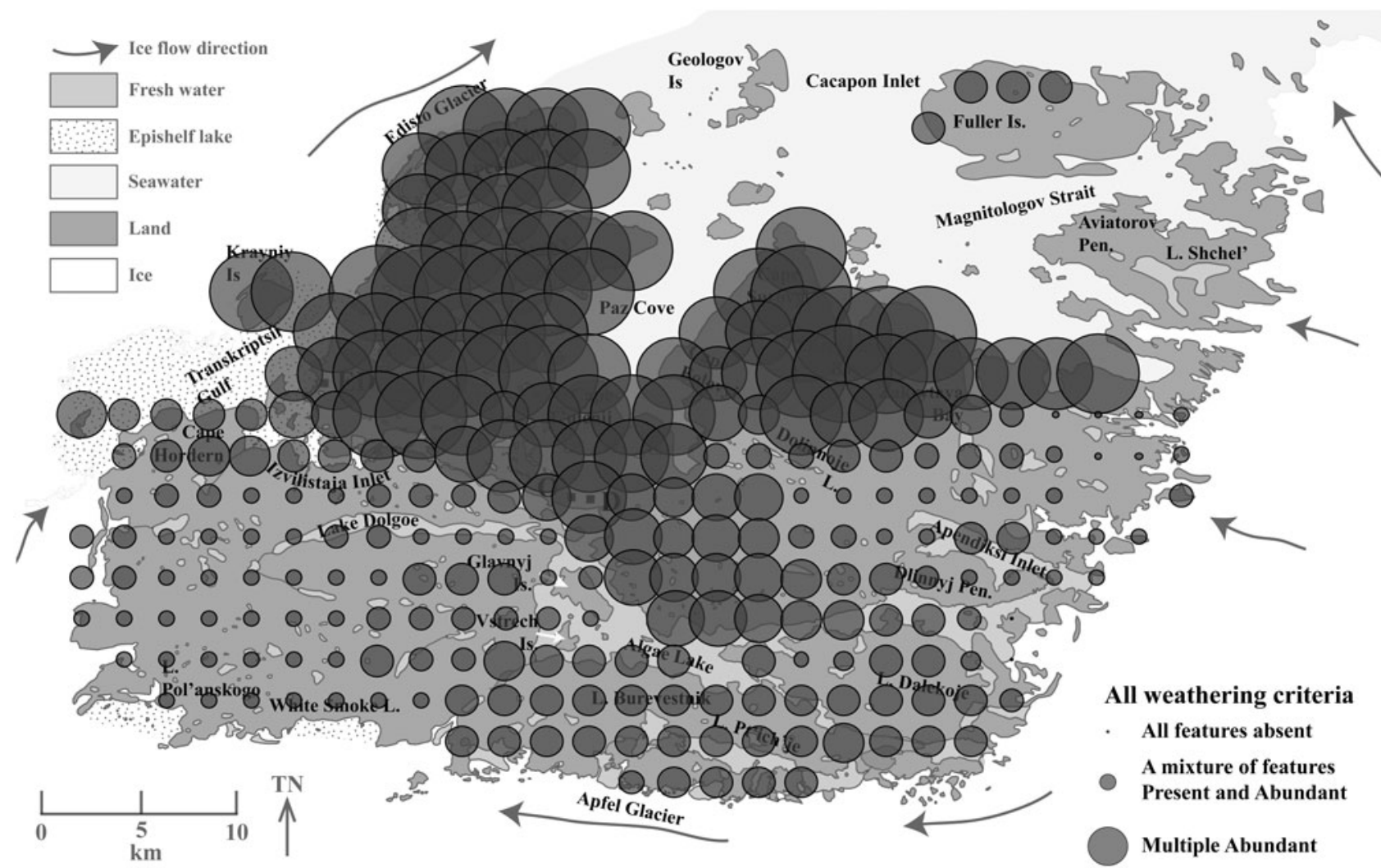

Fig. 4. Weathering index at Bunger Hills, showing strongly weathered northern and north-western areas. Areas to the east and south-west are little weathered. The central area is slightly more weathered, possibly due to a long period of subaerial exposure.

\section{Glacial debris grain size}

Mean grain size of the $<2 \mathrm{~mm}$ fraction of the glacial sediment matrix ranged from $0.18 \mathrm{~mm}$ (fine sand) to $0.56 \mathrm{~mm}$ (coarse sand), with a geometric mean of $0.33 \mathrm{~mm}$ (Fig. $5 \&$ Table SII). The central area of the hills had the smallest mean grain sizes, with larger mean sizes around the ice marginal areas to the east, southeast and south-west (Fig. 5). Sediment sorting ranged from $0.02 \mathrm{~mm}$ (moderately sorted) to $0.55 \mathrm{~mm}$ (extremely poorly sorted), with a geometric mean of $0.25 \mathrm{~mm}$ (poorly sorted). Sediments were typically better sorted (had smaller size values) in the central area of the hills, with instances of poorer sorting around the margins of the ice-free area (Fig. 5). Skewness in Bunger Hills glacial sediments ranged from 0.60 (strongly fine skewed; with an excess of fine grains) to -0.91 (strongly coarse skewed; with an excess of coarse grains), with a mean value of -0.14 (coarse skewed; with an excess of coarse grains). Sediments at the edge of Apfel Glacier were negatively skewed (an excess of coarse grains), while a minority of sediments, mainly in the central and eastern areas towards the ice-sheet margin, were positively skewed (an excess of fine grains) (Fig. 5).

Field observations of tafoni (Figs 2 \& 3) and sand accumulations were only weakly related to sediment grain-size characteristics. Areas with 'abundant' tafoni had a slightly but significantly smaller grain size (average $=0.30 \mathrm{~mm}$ ) than areas where tafoni was 'present' (average $=0.35 \mathrm{~mm}$ ) to 'absent' (average $=0.36 \mathrm{~mm}$ ) $(F=4.21, P=0.0191, \mathrm{df}=2,67)$. However, there were no differences in sorting $(F=0.21, P=0.8136, \mathrm{df}=2,67)$ or skewness $(F=0.74, P=0.4829$, df $=2,67)$ between the three tafoni abundance categories. Similarly, areas with 'abundant' sand accumulations had a slightly but significantly smaller grain size (average $=0.28 \mathrm{~mm}$ ) than areas where sand accumulations were 'present' (average $=$ $0.34 \mathrm{~mm})$ to 'absent' (average $=0.35 \mathrm{~mm})(F=3.38$, $P=0.0403, \quad \mathrm{df}=2,67)$. However, there were no differences in sorting $(F=2.67, P=0.0765, \mathrm{df}=2,67)$ or skewness $(F=0.62, P=0.5386, \mathrm{df}=2,67)$ between the three sand accumulation abundance categories.

\section{Surface sediment conductivity and solute elemental composition}

Conductivity and concentrations of water-extractable $\mathrm{Na}$, $\mathrm{Mg}, \mathrm{Cl}, \mathrm{K}$ and $\mathrm{Ca}$ were greatest in the north of Bunger Hills, with maxima to the south and west of Paz Cove and near the marine inlet of Zakrytaya Bay (Fig. 6 \& Table SIII). The boundary between the area to the north 

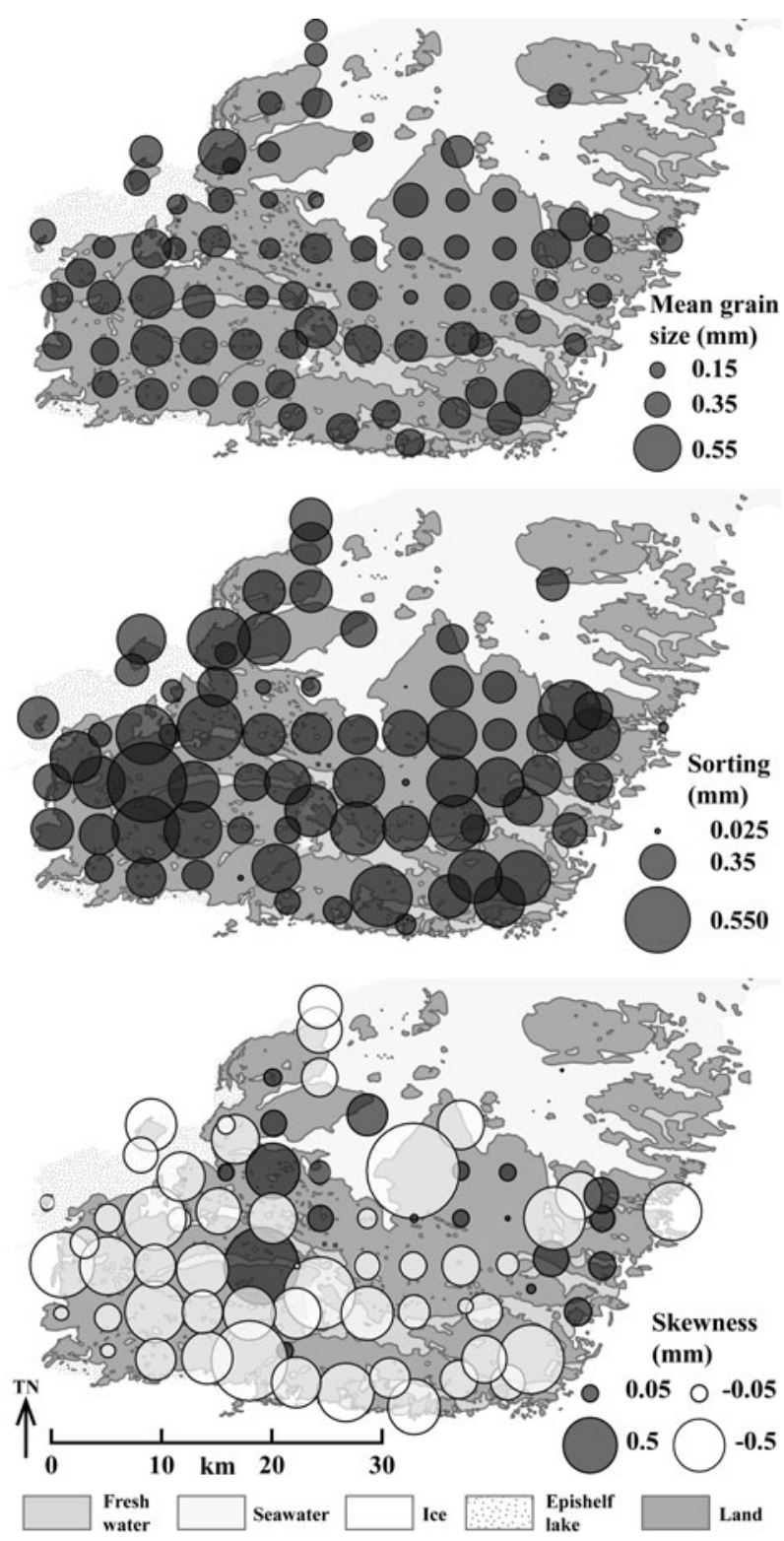

Fig. 5. Glacial sediment grain size parameters for the $<2 \mathrm{~mm}$ fraction. Top panel: mean grain size. Middle panel: sorting. Lower panel: skewness. Dark circles have positive skewness while white circles have negative skewness.

with greater concentrations of extractable ions follows the coastline. There was slightly more extractable $\mathrm{Mg}$ and $\mathrm{K}$ in the south-east of the hills, south of Algae Lake. All analytes were positively and significantly correlated, with the strongest correlation being between $\mathrm{Na}$ and $\mathrm{Cl}$ and the weakest being between $\mathrm{K}$ and $\mathrm{Ca}$ (Table II).

Analysis of variance revealed that large sediment conductivities were significantly correlated with the presence of tafoni $(F=8.66, P=0.0002, \mathrm{df}=3,227)$, orientated wind pits $(F=11.13, P<0.0001, \mathrm{df}=3,227)$ and sand accumulations $(F=3.69, \quad P=0.0264$, $\mathrm{df}=3,227)$ and the absence of frost cracks $(F=5.47$,
$P=0.0048, \mathrm{df}=3,227)$. Conductivity was not related to the presence or absence of glacial polish $(F=1.59$, $P=0.206, \mathrm{df}=3,227)$. Similarly, concentrations of $\mathrm{Cl}$ were significantly correlated with the presence of tafoni $(F=8.96, \quad P=0.0002, \quad \mathrm{df}=3,227), \quad$ orientated wind pits $(F=11.02, \quad P<0.0001, \quad \mathrm{df}=3,227) \quad$ and sand accumulations $(F=3.85, P=0.0228, \mathrm{df}=3,227)$ and the absence of frost cracks $(F=5.67, P=0.0040, \mathrm{df}=3,227)$. As with conductivity, $\mathrm{Cl}$ was not correlated with the presence or absence of glacial polish $(F=1.73$, $P=0.1791$, $\mathrm{df}=3,227)$. Table II suggests that similar, although weaker patterns will emerge with $\mathrm{Na}, \mathrm{Mg}$, $\mathrm{K}$ and $\mathrm{Ca}$.

\section{Salt mineralogy}

The 122 salt samples consisted of 17 minerals: the evaporites halite $(\mathrm{NaCl})$ and thenardite $\left(\mathrm{Na}_{2} \mathrm{SO}_{4}\right)$; the calcium carbonates calcite (trigonal $\mathrm{CaCO}_{3}$ ), aragonite (orthorhombic $\mathrm{CaCO}_{3}$ ) and dolomite $\left((\mathrm{Ca}, \mathrm{Mg}) \mathrm{CO}_{3}\right)$; and the rock weathering products gypsum $\left(\mathrm{CaSO}_{4} \cdot 2 \mathrm{H}_{2} \mathrm{O}\right)$ and 11 rarer minerals (Figs 3, 7 $\& 8 \&$ Table SIV). In order to help explore the spatial patterns of these minerals, five groups have been displayed: halite or thenardite; calcite; aragonite; gypsum; and other weathering products (Fig. 7). The evaporites halite or thenardite were found in $40(33 \%)$ of the 122 samples across most of Bunger Hills, mainly in small closed basins, and dominantly in the north of the hills, where they appeared almost to the exclusion of all other salt minerals. Their abundance dropped markedly to the south, and they were almost absent south of Algae Lake (Fig. 7). Calcite occurred in 59 (48\%) of the 122 samples, and it appeared mostly in the southern parts of the hills. Of the 59 samples containing calcite, other minerals were found in 19 of them and the remaining 40 were pure calcite, which occurred in the south-central and south-eastern parts of the hills. The mineral aragonite occurred in $29(24 \%)$ of the 122 samples, and pure aragonite occurred in only 9 of these: the remaining 20 samples were mostly mixed with calcite. Aragonite occurred mostly across the southern parts of the hills. Gypsum occurred in $13(11 \%)$ of the 122 samples, and in only 1 sample was pure; the others were mixed with other complex minerals that form via rock weathering (Table SIV). The final group, weathering products, occurred in $20(16 \%)$ of the 122 samples, and in all cases except 1 they occurred with a range of other salt minerals.

\section{Discussion}

In the Introduction section, we asked whether or not Bunger Hills had strong patterns of rock weathering and 

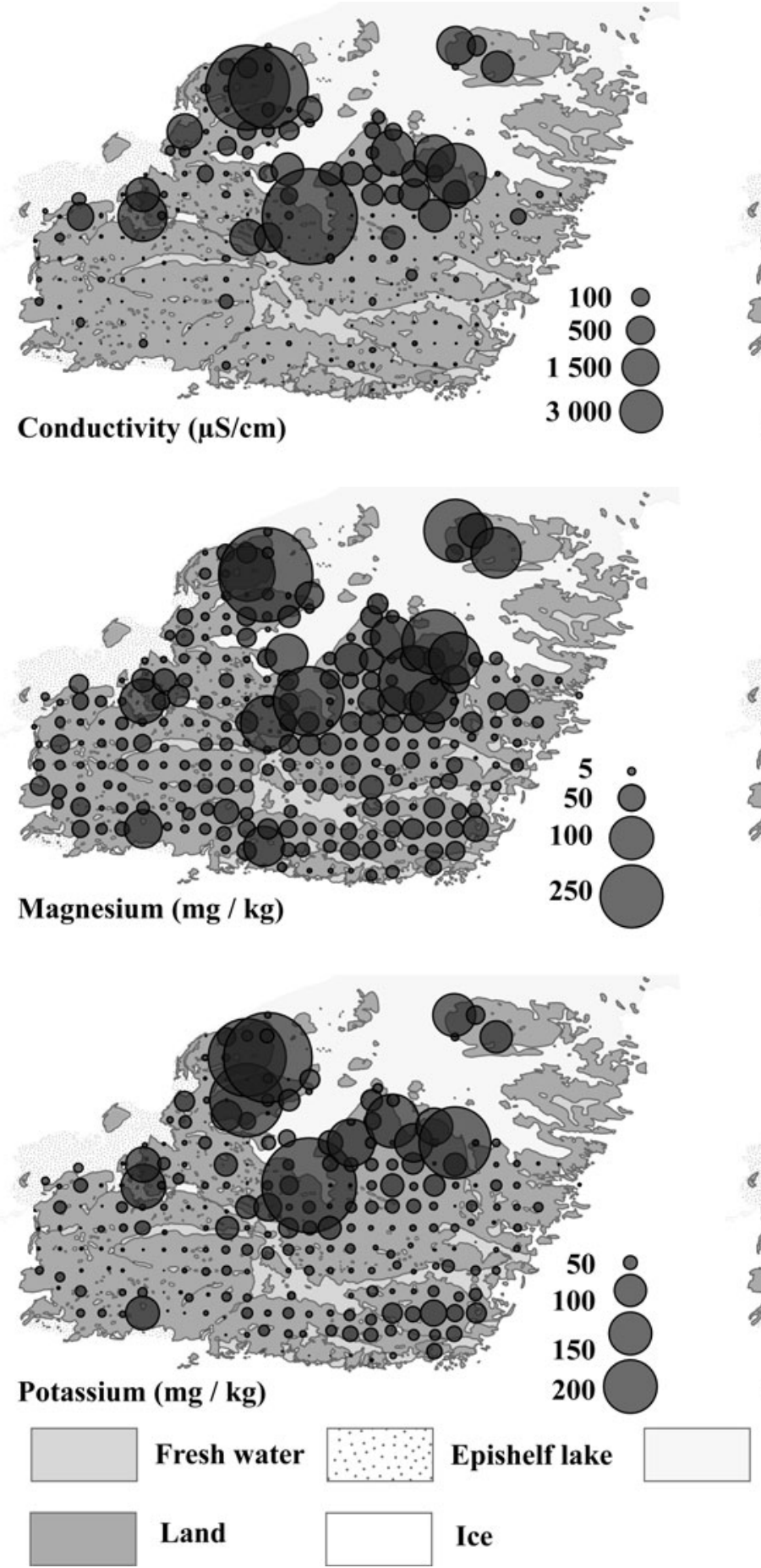
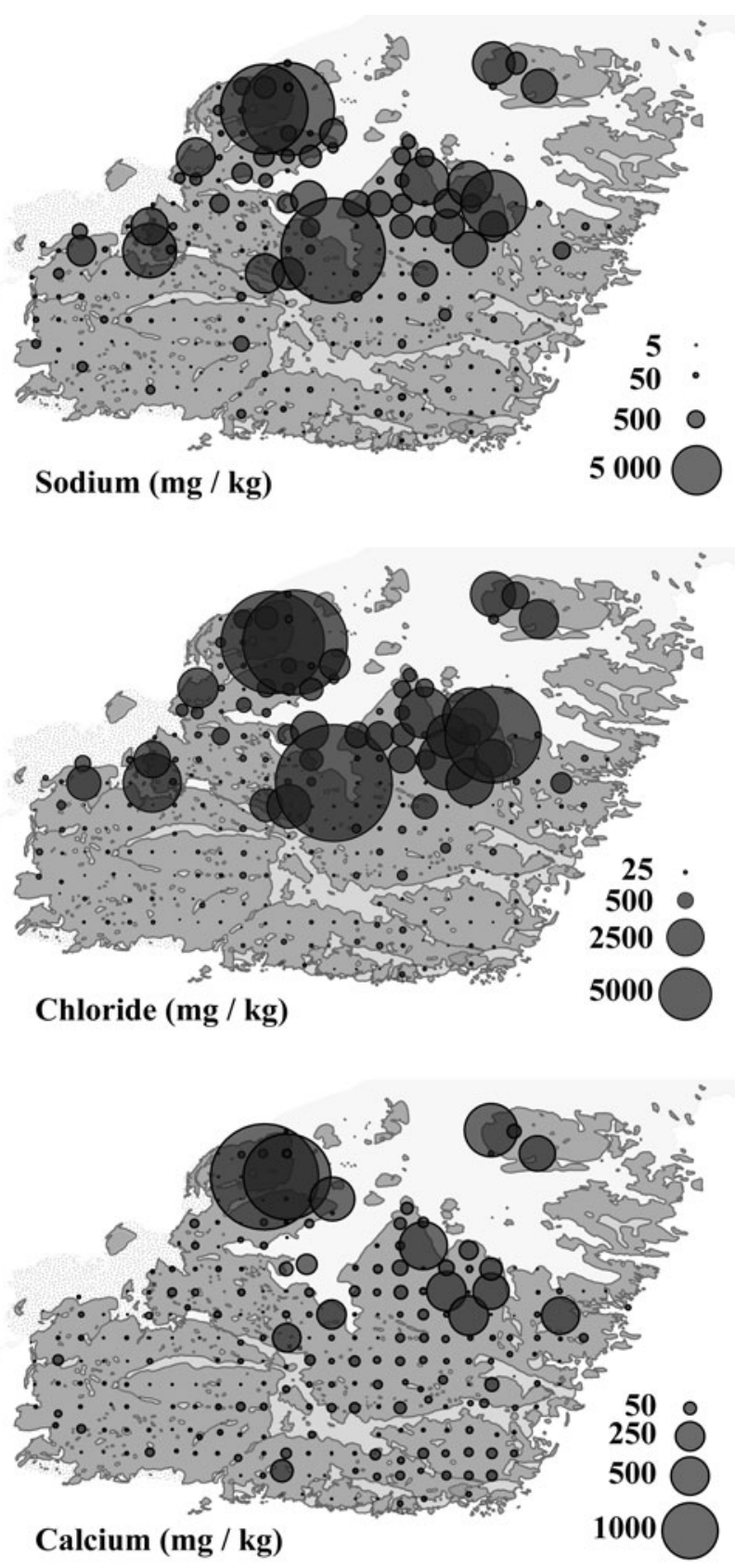

Seawater

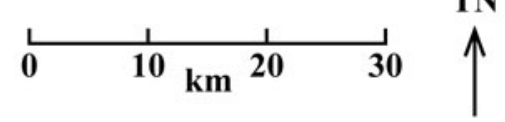

Fig. 6. Conductivity and concentrations of water-extractable $\mathrm{Na}, \mathrm{Mg}, \mathrm{Cl}, \mathrm{K}$ and $\mathrm{Ca}$ in leachates from surface sediments.

sediment development, and whether or not those patterns are associated with the chemistry of sediment solutes and salt mineralogy. We found strong patterns in rock weathering, with almost mutually exclusive patterns of remnant glacial polish in the east and south-east, $v s$ tafoni, orientated wind pits and sand accumulations in the north and north-west (Fig. 2).
Glacial polish is the smooth rock surface, commonly striated, which is left behind by sliding ice. This surface manifestation of physical abrasion by ice, once removed by subaerial weathering, is not replaced until the rock surface is glaciated by sliding ice once again. Therefore, if glacial polish is present, it is reasonably certain that subaerial weathering of the rock surface has been 
Table II. Correlation matrix of the solutes from the surface sediments. Pearson correlation values are shown; the $P$ value for each interaction was $<0.0001$.

\begin{tabular}{lccccr}
\hline & Conductivity & $\mathrm{Na}$ & $\mathrm{Mg}$ & $\mathrm{Cl}$ & $\mathrm{K}$ \\
\hline $\mathrm{Na}$ & 0.984 & & & & \\
$\mathrm{Mg}$ & 0.808 & 0.779 & & & \\
$\mathrm{Cl}$ & 0.987 & 0.979 & 0.813 & & \\
$\mathrm{~K}$ & 0.821 & 0.825 & 0.758 & 0.823 & \\
$\mathrm{Ca}$ & 0.648 & 0.719 & 0.650 & 0.697 & 0.596 \\
\hline
\end{tabular}

minimal since deglaciation. The absence of glacial polish from most rock surfaces across Bunger Hills can be used to infer that postglacial lowering of the rock surfaces has occurred over most of the field area, with the notable exception of the area within $2-5 \mathrm{~km}$ of the ice sheet and the south-east, south of Algae Lake (Fig. 2). The occurrence of glacial polish in these locations reflects either relatively recent deglaciation or a slower rate of surface lowering by erosion there compared with the remainder of Bunger Hills. Glacial polish is found on rock surfaces in eastern and south-eastern Bunger Hills. In contrast, glacial polish is absent from the remainder of Bunger Hills, with the exception of small areas near the western ice margin, where Edisto Glacier formerly expanded onto the land for some hundreds of metres. The eastern and south-eastern areas are poorly constrained for the time duration since deglaciation, and rates of rock surface lowering there are unknown, so the significance of the glacial polish on rock surfaces there needs to be inferred from other evidence.

Those areas to the east and south-east that have remnant glacial polish also have modest sediment conductivities and major ion chemistries (Fig. 6), and their salt mineralogies (Fig. 7) do not reflect a marine influence that might be used to infer salt-enhanced weathering. Crystal growth pressure exerted by minerals that form from the evaporation of seawater, such as halite $(\mathrm{NaCl})$ and thenardite $\left(\mathrm{Na}_{2} \mathrm{SO}_{4}\right)$, results in the spallation of single and small groups of grains (e.g. Sperling \& Cooke, 1985), which is collectively referred to as 'salt weathering'. The solutes in sea spray allow these salt crystals to grow, enhancing the physical weathering of the bedrock and sediment, leading to the appearance of great age in some materials relative to others of the same age of formation. In this way, these purely environmental phenomena may create spatial patterns of rock and sediment weathering that appear to have been caused by glacial advances, or stillstands during ice recession. In turn, this may lead to erroneous

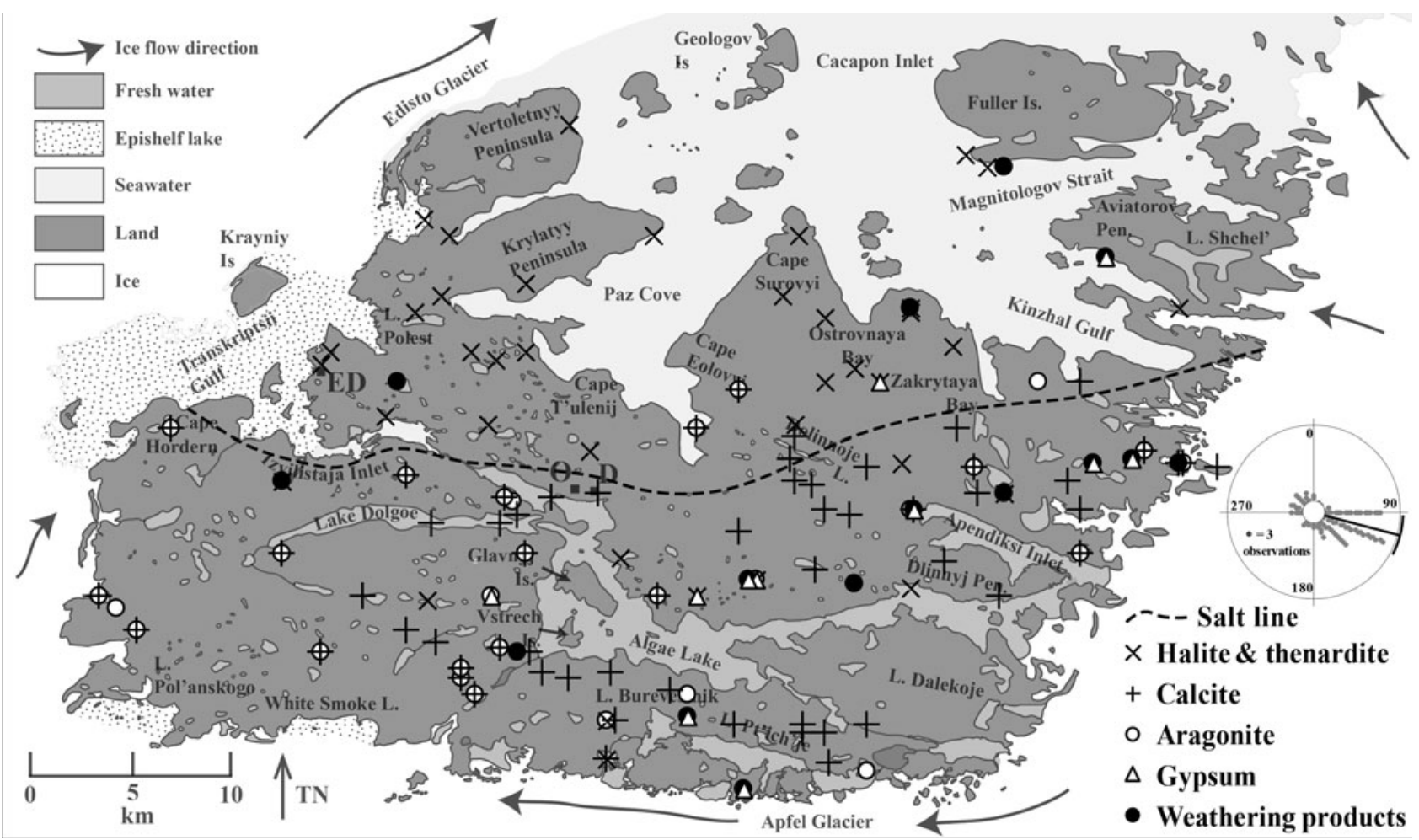

Fig. 7. Mineralogy of salts at Bunger Hills. Evaporites (halite and thenardite) are almost solely towards the northern half of Bunger Hills, while calcites, aragonites and weathering products are most common in the southern half of Bunger Hills. The salt line (discussed in the text), which reflects marine salts to the north and subglacial and weathering products to the south, is plotted as a dashed line. $\mathrm{D}=$ Dobrowolski Station, $\mathrm{ED}=$ Edgeworth David Base, $\mathrm{O}=$ Oasis-2 Station. 

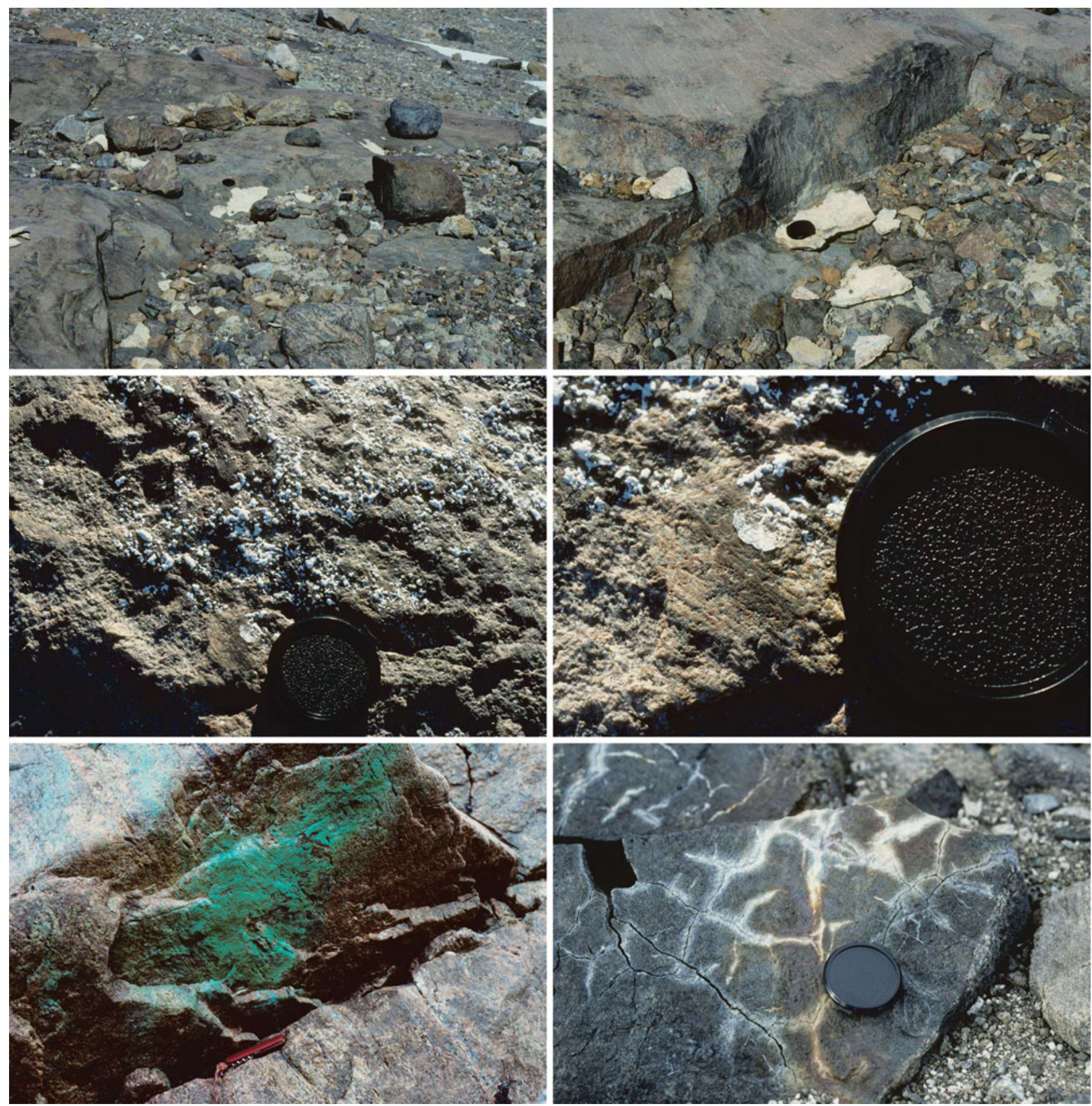

Fig. 8. Top left and top right panels: subglacial calcium carbonate precipitates attached (top left panel) and detached (top right panel) from the lee (down-ice flow) side of striated rock surfaces (lens cap is $50 \mathrm{~mm}$ diameter in all images). Mid-left panel: authigenic calcite $\left(\mathrm{CaCO}_{3}\right)$. Mid-right panel: detail of authigenic calcite showing growth over a striated surface. Bottom left panel: atacamite $\left(\left(\mathrm{Cu}_{2} \mathrm{Cl}(\mathrm{OH})_{3}\right)\right)$ forming on a copper-rich layer of gneiss (knife is $83 \mathrm{~mm}$ long). Bottom right panel: gypsum $\left(\mathrm{CaSO}_{4} \cdot 2 \mathrm{H}_{2} \mathrm{O}\right)$ lining cracks in a mafic rock.

interpretations of glacial history based on weathering characteristics.

The orientated weathering pits (Fig. 2) show that strong winds have blown towards the west since deglaciation, as they still do in the present day (Gore \& Leishman 2020). As a consequence, every summer when lake and sea ice breaks out, salt spray blows over the land towards the west from every marine inlet and saline or hypersaline lake. In turn, this has created surface sediments that have become enriched in the solutes present in seawater. Much of the land in the central and northern area that is lower than $\sim 10 \mathrm{~m}$ above present-day sea level would also have been saturated with seawater during the mid-Holocene relative sea level highstand (Zwartz et al. 1998, Berg et al. 2020). 
Sediment conductivity and the concentration of the analytes $\mathrm{Na}, \mathrm{Mg}, \mathrm{Cl}, \mathrm{K}$ and $\mathrm{Ca}$ exhibited greatest values in the central-north and northern areas of Bunger Hills (Fig. 6), in the areas downwind (westward; Gore \& Leishman 2020) of marine bays and inlets. These analytes are all positively correlated with each other (Table II), suggesting that the sediments have undergone similar enrichment pathways for these solutes. At Bunger Hills, the geometric mean of the elemental abundances in the sediment extracts followed the order $\mathrm{Na}>\mathrm{Cl}>\mathrm{Ca}>\mathrm{K}>\mathrm{Mg}$. However, average global seawater has elemental abundances in the order $\mathrm{Cl}>\mathrm{Na}>\mathrm{Mg}>\mathrm{Ca}>\mathrm{K}$, and water sampled elsewhere in Antarctica and reported by Abollino et al. (2001) follows the same pattern. If the extractable elements at Bunger Hills were solely from sea spray or other marine influence, it follows that they should also have similar rankings in their elemental abundance, but this is not so. Instead, Bunger Hills sediments have greater relative abundances of $\mathrm{Na}, \mathrm{Ca}$ and $\mathrm{K}$ than does seawater. In addition, while Bunger Hills sediment extracts are all positively correlated (Table II), similar examination of Antarctic seawater data (from table 3 in Abollino et al. 2001; data analysed as per our Table II and Table SV) shows weak, positive and non-significant relationships between concentrations of $\mathrm{Na}$ and each of $\mathrm{Mg}, \mathrm{K}$ and $\mathrm{Ca}$ (Table III). The reasons for these differences in ranking of elemental abundances and their stronger correlations at Bunger Hills are not clear, but they must relate to the contributions of ions released from chemical weathering of the gneiss bedrock and, where it exists, glacial sediment above it or nearby. Solutes can then move around in the sediment with meltwater. In general, however, the solutes from the surface sediments (Figs 3, $6 \& 7$ ) reflect the accession of marine-derived salt spray.

Patterns in sediment grain size were also identified. In the central parts of the hills, and particularly west of Paz Cove, the glacial sediment is finer grained, better sorted and has zero to positive skewness, indicating that there is a slight excess of fine-grained material (Fig. 5). In contrast, along the ice margins and particularly to the south and west, the sediments are coarser, slightly less well sorted and have strongly negatively skewed grain-size distributions, indicating an excess of coarse material. These grain-size data are consistent with the centre and north of the hills being areas of long-term salt weathering, in which a unimodal, fine to very fine sand and even silt-sized grains are generated, which then lie on the land surface. Salt weathering and frost shattering reduce larger clasts into gravels and sands, as particles are cleaved along crystal grain boundaries and finer cracks and grain impurities. The terminal grain size of minerals due to freeze-thaw activity in the Bunger Hills foliated gneisses is unknown, but elsewhere silt
Table III. Correlation matrix of analytes in Antarctic seawater from Ross Sea ( $n=30$ measurements; data from Abollino et al. 2001; see also Table SV). Pearson correlation values are shown on top in plain font, while the $P$ value for each interaction is shown underneath the correlation value in italics.

\begin{tabular}{lrrr}
\hline & $\mathrm{Na}$ & $\mathrm{Mg}$ & $\mathrm{K}$ \\
\hline $\mathrm{Mg}$ & 0.1522 & & \\
& 0.4220 & & \\
$\mathrm{~K}$ & 0.1343 & 0.9483 & \\
& 0.4793 & $<0.0001$ & 0.8648 \\
$\mathrm{Ca}$ & 0.2442 & 0.8975 & $<0.0001$ \\
& 0.1934 & $<0.0001$ & \\
\hline
\end{tabular}

(0.063-0.002 $\mathrm{mm}$ size range) particle sizes may be attained through freeze-thaw activity (Schwamborn et al. 2012), which would be sufficient to drive the spatial patterns observed at Bunger Hills. Ice advancing over a pre-glacial weathering surface, which would have been similar to the land surface that exists today, would incorporate this abundant fine sandy sediment and move it a short distance down-ice, redepositing it as glacial till. This additional fine sand to silt changed the grain size of the bulk glacial sediment, making it finer, better sorted and with a more symmetrical distribution than the glacial sediments found around the present-day ice margin. Because these sediments were sampled from the underlying basal or ablation till, the ice must have advanced over a pre-glacial weathering surface similar to that which exists today. This may have occurred through multiple interglacial and glacial cycles, although this conjecture awaits further investigation.

Salts are found commonly in Bunger Hills: under rock overhangs, on sediment surfaces and around small ponds. Most are white, while some are cream or yellow, and some bright green. The taste of the salts varies from table salt to a range of other flavours that are difficult to describe. It was clear that salt composition was different around Bunger Hills, and mineralogical analyses (Fig. 7) identified salts that could be considered in three groups. The most abundant salts in the field were halite and thenardite, whose chemistry and field relationships downwind of marine inlets and in former evaporation basins are consistent with the evaporation of seawater or sea spray from rock and sediment surfaces (Fig. 3). These salts, mainly in the northern parts of the hills, occur in areas where rock weathering is best developed. In these areas, rock surfaces are free from glacial polish, while tafoni, orientated wind pits and accumulations of sand testify to the breakdown of rock surfaces and sediments. These areas, particularly in the north and north-west of the hills, are biogeographically distinct as a consequence of this salinity (Leishman et al. 2020), with a reduction in plant abundance and species richness in the salty areas. The naming of a 'salt line', similar to the salt lines at Vestfold Hills (Blandford 1975, 
Adamson \& Pickard 1986, Gore et al. 1996) and Larsemann Hills (Kiernan et al. 2009), appears to be justified by the rock weathering patterns (Fig. 2), sediment chemistry (Fig. 6) and salt mineralogy (Fig. 7).

A second group, consisting of the calcium carbonate polymorphs aragonite and calcite, may form in several ways. The first is as subglacial precipitates, made clear by their field occurrence on the down-ice side of plucked rock steps (Fig. 8) and in places by the abundant sand and fine gravels entrained in the subglacial environment. The genesis of these subglacial precipitates is well documented from Antarctica (Aharon 1988, Gore et al. 1996) including Bunger Hills (Augustinus et al. 1997), as well as glaciated environments elsewhere (e.g. Hallet 1976). However, not all calcium carbonate minerals were derived subglacially, and there are many occurrences where calcite appears to be a product of either chemical weathering of calcium-rich rocks, or possibly dissolution and re-precipitation of subglacial aragonite and calcite minerals nearby. Such salts have various appearances, occur on top of striated rock surfaces where subglacial precipitates occur very rarely and are clean of subglacial silts and sands (Fig. 8). A further mechanism by which calcite may form is precipitation from evaporating seawater brines (Bjørlykke 1989), but at Bunger Hills this mechanism appears to be rarer, probably as evaporation basins are uncommon. Aragonite and calcite occur rarely north of the salt line. The reasons for this are that the rock surfaces to the north are strongly weathered and so the carbonates do not survive at their site of initial precipitation. Once dislodged from the rock surface, they are readily broken down by salt crystallization pressures and degrade into small pieces in the sediment, where small white flakes can be observed as the remnants of former coherent crusts. To the south of the salt line, the calcites can be preserved in situ.

The third group of salts are gypsum and rarer authigenic weathering products. Gypsum can be formed either from rock weathering or precipitation from seawater (Bjørlykke 1989), but its occurrence in almost all cases with rarer products of rock weathering suggests that, at Bunger Hills, gypsum has formed dominantly by rock weathering. The rock weathering products at Bunger Hills represent tangible evidence that chemical weathering is occurring in the present day. A spectacular green salt, atacamite $\left(\mathrm{Cu}_{2} \mathrm{Cl}(\mathrm{OH})_{3}\right)$, developed on a copper-rich gneiss (Fig. 8) can be traced for hundreds of metres north from Apendiksi Inlet (Fig. 1). Many of these salts are soluble, and as rare rainfall becomes more common at Bunger Hills with changing climate, evidence of these salts on rock surfaces may be washed away and lost.

At Bunger Hills, understanding the terrestrial environment is complicated not only by the age since deglaciation, but also by the flux and concentration of sea spray resulting in enhanced physical rock weathering in some places. This process, whereby a salty, weathered landscape might form relatively rapidly under enhanced salt flux or through subaerial exposure under less salty conditions over a longer period, is similar to the notion of landscape convergence, or equifinality, used in practical applications of geomorphology (e.g. Nicholas \& Quine 2010). In such weathered areas, and with ergodic reasoning, where location and time can substitute (e.g. Fryirs et al. 2012), both absolute dating (e.g. Gore et al. 2001) and understanding the pattern of environmental vectors including salt are required. A detailed understanding of salt, sediments and the weathering environment allows for much more nuanced understanding and reconstruction of glacial history and the distributions of biota and their habitats.

\section{Conclusions}

Regional patterns exist in the weathering environment, the composition of surface sediments, the mineralogy of salt and the grain size of glacial sediment at Bunger Hills. Field observations reveal that tafoni and orientated wind pits in rock surfaces and sand accumulations on the land surface are common in the north of the field area, whereas glacial polish on rock surfaces and frost cracks in sediment are rare in the same area.

Analyses of electrical conductivity and waterextractable $\mathrm{Na}, \mathrm{Mg}, \mathrm{Cl}, \mathrm{K}$ and $\mathrm{Ca}$ in leachates from surface sediments show that the north of the field area is rich in solutes. The mineralogy of salts shows that the north of the field area is dominated by halite and thenardite, probably derived from sea spray. To the south, east and west, salts are either calcite, aragonite, gypsum or rarer rock weathering products.

Seawater-derived salts, particularly halite and thenardite, are known from a range of environments to aggressively weather rocks, and their distribution at Bunger Hills is consistent with field observations of weathering, geomorphology and the chemical composition of surface sediments. The salt from sea spray may lead to the appearance of great age in some rock surfaces relative to others, creating spatial patterns of rock and sediment weathering similar to those resulting from stillstands or re-advances of glacial ice. Understanding the effects of salt may help to prevent erroneous interpretations of deglaciation patterns and timings based solely on weathering characteristics.

The grain size of the glacial sediment is also a window into the palaeoenvironment of Bunger Hills during the last period of deglaciation. The correlation of sediment grain size with present-day areas of abundant tafoni development and sand accumulation indicates that the areas that are strongly weathered today were also 
strongly weathered prior to the last glacial advance over the field area. Whether this was due to salt-enhanced weathering, extended subaerial exposure of the northern parts of the field area or both awaits further investigation.

This research commenced with the questions of whether or not there are spatial patterns of rock weathering and sediment development at Bunger Hills, and if present, whether those patterns were associated with the chemistry of solutes readily extracted from surface sediments and the mineralogy of salts on the land surface. We found that spatial patterns of weathering, geochemistry and sediment exist, and we conclude that these patterns are driven largely by salt weathering over extended durations during interglacial periods. The marine salt-rich area changes the geochemical and, over time sedimentological character in response to the accession of salt and the degradation of rock surfaces. Only after consideration of the interactions of various salt minerals with the geochemical, weathering and sedimentary environments will the glacial history and palaeoenvironment of Bunger Hills and similar field areas be fully understood.

\section{Acknowledgements}

We thank Paul Augustinus, Don Hudspeth and Dan Zwartz for help in the field, Jim Burgess for analysing the sediments for conductivity and extractable elements, Mike Ashelford for drafting the figures and reviewers for improving the manuscript.

\section{Author contributions}

Both authors conceived the ideas and conducted fieldwork, data analysis, writing and proofing of the manuscript.

\section{Financial support}

We thank the Australian Antarctic Division for logistical and financial support under AAS 926.

\section{Supplemental material}

Five supplemental tables will be found at https://doi.org/ 10.1017/S0954102020000073. These data are also in the Australian Antarctic Data Centre at http://data.aad. gov.au/metadata/records/AAS_926_Bunger_Hills_Salt_ Sediment_Weathering (10.26179/5e1fa087f185c).

\section{References}

Abollino, O., Aceto, M., la Gioia, C., Sarzanini, C. \& Mentasti, E. 2001. Spatial and seasonal variations of major, minor and trace elements in Antarctic seawater. Chemometric investigation of variable and site correlations. Advances in Environmental Research, 6, 29-43.
Adamson, D.A. \& Colhoun, E.A. 1992. Late Quaternary glaciation and deglaciation of the Bunger Hills, Antarctica. Antarctic Science, 4, 435-446.

AdAmson, D.A. \& PiCKard, J. 1986. Physiography and geomorphology of the Vestfold Hills. In PicKard, J., ed. Antarctic oasis. Sydney: Academic Press, 99-139.

Aharon, P. 1988. Oxygen, carbon and U-series isotopes of aragonites from Vestfold Hills, Antarctica: clues to geochemical processes in subglacial environments. Geochimica et Cosmochimica Acta, 52, 2321-2331.

Augustinus, P.C., Gore, D.B., Leishman, M.R., Zwartz, D. \& Colmoun, E.A. 1997. Reconstruction of ice flow across the Bunger Hills, East Antarctica. Antarctic Science, 9, 347-354.

Berg, S., Melles, M., Gore, D.B., Verkulich, S. \& Pushina, Z. 2020. Postglacial evolution of marine and lacustrine water bodies in Bunger Hills. Antarctic Science, 32, 10.1017/S0954102019000476.

BJørlykke, K.O. 1989. Sedimentology and petroleum geology. Berlin: Springer, $363 \mathrm{pp}$.

BLANDFORD, D.C. 1975. Spatial and temporal patterns of contemporary geomorphic processes in the Vestfold Hills. B.Litt. thesis, University of New England, 137 pp. [Unpublished].

Colmoun, E.A. \& Adamson, D.A. 1992. Raised beaches of the Bunger Hills, Antarctica. ANARE Reports, No. 136, 47 pp.

Cromer, L., Gibson, J.A.E., Swadling, K.M. \& Hodgson, D.A. 2006. Evidence for a lacustrine faunal refuge in the Larsemann Hills, East Antarctica, during the Last Glacial Maximum. Journal of Biogeography, 33, 1314-1323.

De Smet, W.H. \& Gibson, J.A.E. 2007. Rhinoglena kutikovae n.sp. (Rotifera: Monogononta: Epiphanidae) from the Bunger Hills, East Antarctica: a probable relict species that survived Quaternary glaciations on the continent. Polar Biology, 31, 595-603.

FoLK, R.L. 1980. Petrology of sedimentary rocks. Austin, TX: Hemphill Publishing, $182 \mathrm{pp}$.

Fryirs, K.A., Brierley, G.J. \& Erskine, W.D. 2012. Use of ergodic reasoning to reconstruct the historical range of variability and evolutionary trajectory of rivers. Earth Surface Processes and Landforms, 37, 763-773.

Gibson, J.A.E., Gore, D.B. \& Kaup, E. 2002. Algae River: an extensive drainage system in the Bunger Hills, East Antarctica. Polar Record, 38, 141-152.

Gore, D.B. \& Leishman, M.R. 2020. Tafoni show postglacial and modern wind azimuths that are similar at Bunger Hills. Antarctic Science, 32, 10.1017/S095410201900035X.

Gore, D.B., Snape, I. \& Leishman, M.R. 2003. Glacial sediment provenance, dispersal and deposition, Vestfold Hills, East Antarctica. Antarctic Science, 15, 259-269.

Gore, D.B., Creagh, D.C., Burgess, J.S., Colhoun, E.A., Spate, A.P. \& BAIRD, A.S. 1996. Composition, distribution and origin of surficial salts in the Vestfold Hills, East Antarctica. Antarctic Science, 8, 73-84.

Gore, D.B., Rhodes, E.J., Augustinus, P.C., Leishman, M.R., Colhoun, E.A. \& Rees-Jones, J. 2001. Bunger Hills, East Antarctica: ice free at the Last Glacial Maximum. Geology, 29, 1103-1106.

GoudIE, A.S. 1986. Laboratory simulation of 'the wick effect' in salt weathering of rock. Earth Surface Processes and Landforms, 11, 275-285.

Hallet, B. 1976. Deposits formed by subglacial precipitation of $\mathrm{CaCO}_{3}$. Geological Society of America Bulletin, 87, 1003-1015.

Kiernan, K., Gore, D.B., Fink, D., McConnell, A., Sigurdsson, I.A. \& White, D.A. 2009. Deglaciation and weathering of Larsemann Hills, East Antarctica. Antarctic Science, 21, 373-382.

Leishman, M.R., Gibson, J.A.E. \& GoRe, D.B. 2020. Spatial distribution of birds and terrestrial plants in Bunger Hills. Antarctic Science, 32, 10.1017/S0954102020000012. 
Nicholas, A.P. \& Quine, T.A. 2010. Quantitative assessment of landform equifinality and palaeoenvironmental reconstruction using geomorphic models. Geomorphology, 121, 167-183.

PiCKARD, J. 1982. Holocene winds of the Vestfold Hills, Antarctica. New Zealand Journal of Geology and Geophysics, 25, 353-358.

PiCKARD, J. 1986. Spatial relations of the vegetation of the Vestfold Hills. In Pickard, J. ed. Antarctic oasis. Sydney: Academic Press, 275-308.

Pugh, P.J.A. \& Convey, P. 2008. Surviving out in the cold: Antarctic endemic invertebrates and their refugia. Journal of Biogeography, 35, 2176-2186.

Schnepfleitner, H., Sass, O., Fruhmann, S., Viles, H. \& Goudie, A. 2016. A multi-method investigation of temperature, moisture and salt dynamics in tafoni (Tafraoute, Morocco). Earth Surface Processes and Landforms, 41, 473-485.
Schwamborn, G., Schirrmeister, L., Frütsch, F. \& Diekmann, B. 2012. Quartz weathering in freeze-thaw cycles: experiment and application to the El'gygytgyn crater lake record for tracing Siberian permafrost history. Geografiska Annaler: Series A, Physical Geography, 94, 481-499.

Sperling, C.H.B. \& CoOKe, R.U. 1985. Laboratory simulation of rock weathering by salt crystallization and hydration processes in hot, arid environments. Earth Surface Processes and Landforms, 10, 541-555.

Tucker, N.M., Hand, M. \& Clark, C. 2020. The Bunger Hills: 60 years of geological and geophysical research. Antarctic Science, 32, 10.1017/S0954102019000403.

Zwartz, D., Bird, M., Stone, J. \& Lambeck, K. 1998. Holocene sea-level change and ice-sheet history in the Vestfold Hills, East Antarctica. Earth and Planetary Science Letters, 155, 131-145. 